main nutrient for the sperm cells, inositol and citrate, found in large amounts in some animals, ergothioneine, various choline compounds and a number of enzymes. This scholarly discussion of many fundamental biological problems should prove of considerable interest also to biochemists and physiologists working in other fields.

The historical background for the development of seminal biochemistry is by no means neglected; some readers may even hold that too much space is devoted to historical matters. In my opinion, however, this historical note is important in a book which will undoubtedly become the standard text in the field, and certainly contributes greatly to make pleasant reading. The illustrations are on the whole very well chosen, but a number of structural formulæ of simple substances (one of which contains two misprints) might well be omitted. The list of about one thousand references, though not complete, will be found very useful, and so will the subject index. Author, editors and publishers are to be con. gratulated upon the production of this excellent monograph.

F. LUNDQUIST

\section{AN ANTHOLOGY OF ANTHROPOLOGY}

\section{Primitive Heritage}

An Anthropological Anthology. Edited, with an Introduction, by Margaret Mead and Nicolas Calas. Pp. $x x x+592$. (London: Victor Gollancz, Ltd., 1954.) 21s. net.

TN a brief introduction to this book, Margaret Mead refers to the change in the type of anthropological literature which has developed in the past halfcentury. The armchair school of collectors of tales and legends was succeeded by the comparative school, which has become more and more dependent for its material on first-hand accounts of the life of individual tribes. In the text itself there is an essay by Ruth Benedict, published in 1932, in which the same attitude is taken. The reader who picks up this book for the first time might therefore expect a marked bias towards writings emanating from the psychological or psychoanalytical school of anthropologists. Any such fears may be discounted. The collaboration between the anthropologist and Nicolas Calas, the distinguished art critic, has produced an extraordinarily interesting anthology which will serve its purpose- to leave the reader often unsatisfied and in the mood to ask for more.

The faimess of the selection can readily be seen by a glance at the contents. The work contains one hundred and eleven extracts, and of these only about seventy date from the present century. The beginnings of the anecdotal school are represented by Herodotus, Tacitus and Strabo. The various parts of the work deal with such fundamental happenings or activities as childbirth, puberty, marriage, war, sport, death and immortality. Even those who have read much of the material in its original form will find renewed pleasure in reading straight through the book, as the reviewer has done. The extracts are very well chosen. There are some surprising omissions; but the compilers would no doubt justify them. Frazer and Westermarck find no place in the book, and it may be suggested that Tylor has just succeeded in gaining a place. Malinowski is well represented, as also are Sapir, Fortune and Rateliffe-
Brown. Hermann Melville gets in twice. The unodern reporter of an international football match might read with profit Catlin's description of the ball game among the Choktaw, written more than a century ago. From the literary aspect one of the finest extracts in the book is written not by a professional writer or by an anthropologist, but by an artistMaya Deren's passage from "Divine Horsemen".

In addition to its extensive use as a bedside-book -which is quite probable-this anthology may well be recommended to the student of anthropology as a rapid introduction to the great literature of the subject. In its next edition the compilers should certainly provide it with an index.

E. AsHWORTH UNDERWOOD

\section{MICROWAVE SPECTROSCOPY}

Microwave Spectroscopy

By Prof. Walter Gordy, Prof. William V. Smith and Prof. Ralph F. Trambarulo. (Structure of Matter Series.) Pp. xii +446. (New York: John Wiley and Sons, Inc.; London: Chapman and Hall, Ltd., 1953.) 64s. net.

MICROWAVE spectroscopy is a comparatively 11 new branch of physics which has arisen out of the development of radar techniques during the Second World War. Already, however, significant contributions have been made to the fields of molecular and solid-state physics. This book, by Profs. W. Gordy, W. V. Smith and R. F. Trambarulo, attempts to survey and to summarize the information which has so recently been accumulated. Thus, it cannot be regarded as a text-book, although many research students will find it a useful and concise introduction to the techniques and results of this branch of spectroscopy. The major part of the book is devoted to topics concerned with the spectroscopy of gases; and although this is perhaps not unex. pected in view of the contributions to this field from Prof. Gordy, nevertheless it does present rather a biased account when, of the three hundred and fifty pages available, only fifty are allocated to the discussion of the microwave investigations of the solid state.

After an introductory chapter on the techniques and design of microwave spectroscopes, there are three chapters summarizing the measurements on gases, one chapter on the microwave spectra of solids and liquids, and four later chapters devoted to nuclear properties, more detailed discussions of molecular structure and possible applications of the microwave experiments in other fields. The book is well written, admirably presented, and there seem to be very few printing errors. There are a large number of helpful diagrams and a valuable collection of references. The appendix contains an impressive amount of data in tabular form.

The book will undoubtedly appeal to the research worker wishing to refer to an up-to-date review of a rapidly expanding branch of physics. A book of this nature, however, suffers from a serious liability, since, in order to maintain its appeal, new editions must be available as the subject advances. In Britain the published price is 64s., and this is scarcely a price which can commend the book to scientific workers anticipating a later edition; many students may decide that the expense of the present edition makes ownership of the book a considerable luxury. 